\title{
SINTESIS GRAFENA DARI LIMBAH PELEPAH SAWIT (Elaeis Sp.) DENGAN METODE REDUKSI GRAFIT OKSIDA MENGGUNAKAN PEREDUKSI Zn
}

(Synthesis Of Graphene From Palm Midrib Waste (Elaeis Sp.) Using Graphite Oxide Reduction Method With Reductor Zn)

\author{
Meyly Ekawati Thebora S., Kurnia Nastira Ningsih, Muhammad Irhash Shalihin \\ Program Studi Kimia Fakultas Sains dan Teknologi Universitas Jambi \\ Jl. Jambi-Ma. Bulian KM 15 Mendalo Darat Jambi 36361 \\ Email : meylyekawati@gmail.com
}

\begin{abstract}
Graphene is a nanomaterial that has high conductivity, can be synthesized from palm midrib waste with dominant components of cellulose, hemicellulose and lignin which are used as carbon sources. This study aims to determine how graphene synthesis and graphene characteristics that produced from palm midrib waste. Graphene synthesis method generally consists of carbonization process, graphite oxide synthesis, then reduction of graphite oxide to graphene. Carbonization of palm midrib using temperature of $300^{\circ} \mathrm{C}$ for 60 minutes and then sieving with 270 mesh size. Graphite oxide (GO) synthesized using the Hummers method, that is oxidation reaction of graphite to graphite oxide with an oxidizer of $\mathrm{KMnO}_{4}$ in an acidic atmosphere $\left(\mathrm{H}_{2} \mathrm{SO}_{4}\right)$ which produces a dark brown mixture. Graphite oxide is obtained as a powder. Furthermore, graphite oxide is reduced to graphene with the $\mathrm{Zn}$ reducing agent in an acidic atmosphere $(\mathrm{HCl})$. The results of the characterization were carried out by comparison of the literature; $X R D$ results show different diffractogram results on graphite, graphite oxide and graphene with reduced crystallinity. FTIR results show the presence of functional groups $\mathrm{O}-\mathrm{H}, \mathrm{C}=\mathrm{O}, \mathrm{C}-\mathrm{OH}$ and $\mathrm{C}-\mathrm{O}$ bonds only in graphite and graphite oxide. SEM results show that sheet-shaped graphene is thinner than graphite oxide. Synthesis of graphene from palm midrib waste can be done using the method of Graphite Oxide Reduction (GO) with the Zn Reductor.
\end{abstract}

Keywords : Graphene, Graphite Oxide, Palm Midrib, Synthesis.

\begin{abstract}
Abstrak
Grafena merupakan nanomaterial yang memiliki konduktivitas tinggi, dapat disintesis dari limbah pelepah sawit dengan komponen dominan selulosa, hemiselulosa dan lignin yang dimanfaatkan sebagai sumber karbon. Penelitian ini bertujuan untuk mengetahui cara sintesis grafena dan karakteristik grafena yang dihasilkan dari limbah pelepah sawit. Metode sintesis grafena secara umum terdiri dari proses karbonisasi, sintesis grafit oksida, kemudian reduksi grafit oksida menjadi grafena. Karbonisasi pelepah sawit menggunakan suhu $300^{\circ} \mathrm{C}$ selama 60 menit yang selanjutnya dilakukan pengayakan berukuran 270 mesh. Grafit oksida (GO) disintesis menggunakan metode Hummers yaitu reaksi oksidasi grafit menjadi grafit oksida dengan oksidator berupa $\mathrm{KMnO}_{4}$ dalam suasana asam $\left(\mathrm{H}_{2} \mathrm{SO}_{4}\right)$ yang menghasilkan campuran berwarna coklat tua. Grafit oksida diperoleh sebagai bubuk. Selanjutnya, grafit oksida direduksi menjadi grafena dengan reduktor $\mathrm{Zn}$ dalam suasana asam $(\mathrm{HCl})$. Hasil karakterisasi dilakukan dengan perbandingan literatur; hasil XRD menunjukkan hasil berbeda pada difraktogram grafit, grafit oksida dan grafena dengan tingkat kristalinitas yang berkurang. Hasil FTIR menunjukkan adanya gugus fungsional $\mathrm{O}-\mathrm{H}$, $\mathrm{C}=\mathrm{O}$, ikatan $\mathrm{C}-\mathrm{OH}$ dan $\mathrm{C}-\mathrm{O}$ hanya pada grafit dan grafit oksida. Hasil SEM menunjukkan grafena berbentuk lembaran yang lebih tipis dari grafit oksida. Sintesis grafena dari limbah pelepah sawit dapat dilakukan dengan menggunakan metode Reduksi Grafit Oksida (GO) dengan Reduktor Zn.
\end{abstract}

Kata kunci : Grafena, Grafit Oksida, Pelepah Sawit, Sintesis. 


\section{PENDAHULUAN}

Kebutuhan energi dunia semakin meningkat termasuk Indonesia, Kementrian Energi dan Sumberdaya Mineral Republik Indonesia (2018), konsumsi energi Indonesia mengalami peningkatan dari tahun ke tahun. Periode 2017 2018, konsumsi energi akhir mengalami peningkatan sebesar $11,27 \%$ dari 780.600 .000 Barrel of Oil Equivalent (BOE) menjadi 868.581.000 BOE.

Menurut jenis energi, tahun 2018 konsumsi energi Bahan Bakar Minyak (BBM) merupakan konsumsi energi tertinggi (336.949.000 BOE) yang diikuti listrik (156.984.000 BOE), biogasoline (113.829.000 BOE), batu bara (100.506.000 BOE) dan gas alam (95.646.000 BOE). Meskipun listrik merupakan sumber energi yang menjanjikan untuk mengganti bahan bakar fosil, namun berdasarkan data dari Direktorat Jenderal Ketenagalistrikan Kementrian ESDM RI (2017), pembangkit listrik yang ada di Indonesia pun masih didominasi oleh pemanfaatan bahan bakar fosil seperti PLTU, PLTG, PLTGU, PLTMG dan PLTD yang menguasai
87,9\% dari keseluruhan kapasitas terpasang pembangkit tenaga listrik nasional. Sementara itu, bahan bakar fosil adalah sumber energi tidak terbarukan yang suatu saat akan habis. Oleh karena itu, dibutuhkan inovasi suatu sumber energi alternatif yang lebih efisien dan terbarukan dimasa depan, serta inovasi baru dibidang energi.

Saat ini, permasalahan energi tidak hanya terfokus pada pencarian sumber energi baru, namun juga inovasi pada material untuk menyimpan energi tersebut. Material terkait energi yang saat ini dikembangkan adalah material dalam bentuk nano (nanomaterial), salah satunya adalah grafena. Grafena merupakan molekul yang terdiri dari atom karbon murni. Grafena adalah lembaran yang sangat tipis yang pernah ada. Grafena juga memiliki konduktivitas listrik yang tinggi. Elektron dalam grafena bersifat relativistik; memiliki kecepatan yang luar biasa. Aplikasi grafena sangat menjanjikan dalam berbagai bidang, khususnya energi seperti sebagai elektroda konduktor transparan, transistor, ultrakapasitor (penangkap dan penyimpan energi) dan anoda 
pada baterai lithium ion ( $\mathrm{Li}$, et al., 2013; Stoller, et al., 2008; Samantara, 2015).

Material grafena pertama kali disintesis oleh Andre K. Geim dan Konstantine Novoselov dari Manchester University, UK pada tahun 2004 dengan cara mengambil satu lapisan tipis karbon dengan ketebalan hanya satu atom yang terdapat pada pensil dengan menggunakan selotip (Yusupandi, 2017). Sekarang ini, untuk mensintesis grafena umumnya digunakan teknologi tinggi seperti metode Mechanical Exfoliation, akan tetapi biaya yang cukup tinggi menjadi salah satu permasalahan utamanya. Untuk itu perlu dilakukan sintesis grafena yang lebih sederhana dan terjangkau yakni dengan menggunakan metode reduksi Grafit Oksida (GO). Secara sederhana grafit dioksidasi menjadi oksida grafit (GO), kemudian lembaran-lembaran oksida grafit tersebut dikelupas (exfoliated) dalam air hingga terbentuk oksida grafena. Konsentrasi oksigen dalam oksida grafena dapat direduksi hingga habis meninggalkan lapisan grafena (Syakir, et al., 2015). Proses yang terjadi dapat dilihat

pada gambar 1.

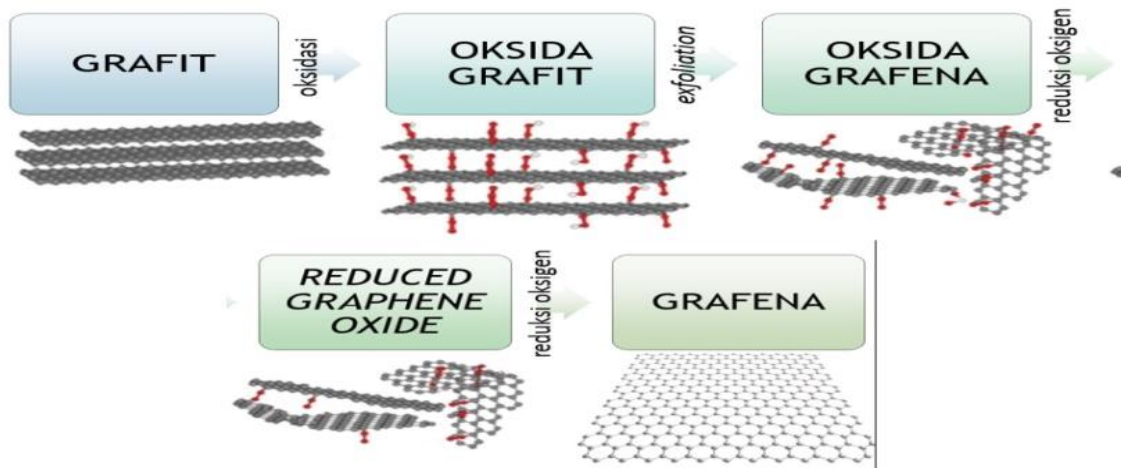

Gambar 1. Skema Pembuatan Grafena dari Grafit

(Sumber : Syakir, et al., 2015)

Sintesis grafena menggunakan (IGO). Hasil uji kristalinitas XRD bahan baku alami telah dilakukan menunjukkan puncak $2 \theta$ pada $26,343^{\circ}$ sebelumnya oleh Sutayasa dan dengan nilai $d$-spacing $0,338050 \mathrm{~nm}$ Sanjaya (2016) dari arang ampas serta ukuran kristal sebesar 15,41 nm. tebu menggunakan metode kimia Hasil uji morfologi TEM menunjukkan modifikasi Improved Graphene Oxide adanya few-layer graphene (FLG) serta 
bagian layer grafena yang sangat tipis dan transparan dimana menunjukkan hasil yang serupa dengan grafena alam.

Limbah organik lain yang juga berpotensi sebagai bahan baku sintesis grafena yaitu limbah pelepah sawit. Analisa kimia terhadap pelepah sawit menunjukkan terdapat kom-ponen selulosa, hemiselulosa dan lignin yang dapat dimanfaatkan sebagai bahan baku karbon karena lignin dan selulosa sebagian besar tersusun dari unsur karbon. Pelepah kelapa sawit termasuk bahan dengan kandungan selulosa yang cukup tinggi dan memiliki massa jenis lebih daripada kayu yaitu sebesar 1,16 g/cm ${ }^{3}$ (Pope, 1999). Kandungan selulosa yang cukup tinggi tersebut lah yang berpotensi dapat diolah lebih lanjut menjadi bahan baku (karbon) dalam sintesis grafena

Tabel 1

Kandungan Senyawa Kimia Penyusun Serat pada Pelepah Kelapa Sawit

\begin{tabular}{cc}
\hline Unsur Kimiawi & Pelepah Kelapa Sawit (\%) \\
\hline Selulosa & 33,7 \\
Hemiselulosa & 35,9 \\
Lignin & 17,4 \\
Silika & 2,6 \\
Abu & 3,3 \\
Nitrogen & 2,38 \\
Kalium & 1,316 \\
Kalsium & 2,568 \\
Magnesium & 0,487 \\
Fosfor & 0,157 \\
Sulfur & 0,40 \\
Klorida & 0,70 \\
\hline
\end{tabular}

Sumber : Ginting dan Elizabeth, 2013

Hal ini didukung oleh fakta bahwa sawit merupakan hasil pertanian yang cukup melimpah, Direktorat Jenderal Perkebunan tahun 2017, Provinsi Jambi tahun 2017 memiliki luas lahan sawit mencapai 463.952 hektar. Dengan asumsi bahwa produksi biomassa pelepah sawit mencapai 6,3 ton per hektar per tahun (Darmayanti, 2016), maka diperoleh perkiraan produksi pelepah sawit di Provinsi Jambi adalah sebesar 2.922.897,6 ton per tahunnya. Namun, pada kenyata-annya pelepah 
sawit selama ini hanya dibakar menjadi arang dan abu yang sering menimbulkan polusi udara. Sehingga perlu dilakukan pemanfaatan terhadap limbah pelepah sawit tersebut agar lebih bernilai dan menghasilkan suatu senyawa yang bermanfaat.

Penelitian sintesis grafena menggunakan limbah pelepah sawit ini memiliki beberapa kelebihan seperti ketersediaan bahan baku yang sangat melimpah dan murah, menggunakan metode kimia berupa Reduksi Grafit Oksida (GO) sehingga tidak memerlukan biaya yang tinggi dan proses sintesis yang cukup sederhana dibandingkan metode kimia lain seperti Improved Graphene Oxide (IGO) dan Chemical Vapor Deposition (CVD).

Berdasarkan latar belakang yang diuraikan di atas, tujuan penelitian ini adalah (1). Mengetahui cara mensintesis grafena dari limbah pelepah sawit; dan (2). Mengetahui karakteristik grafena yang dihasilkan dari pelepah sawit. Dengan adanya penelitian ini diharapkan dapat memberikan referensi kepada instansi penelitian dan ilmu pendidikan mengenai informasi bahwa limbah pelepah sawit dapat disintesis menjadi material grafena, yang merupakan material yang memiliki banyak aplikasi, terutama dalam bidang energi dan teknologi. Hal ini kemudian dapat meningkatkan nilai ekonomi dari limbah pelepah sawit itu sendiri.

\section{LANDASAN TEORI}

\section{Grafena}

Grafena merupakan alotrop karbon dengan bentuk dua dimensi dan berikatan secara heksagonal. Grafena merupakan penyusun dasar dari alotrop karbon lainnya seperti grafit, arang, carbon nanotubes dan fullerenes. Panjang ikatan C - C pada grafena sebesar 1,42 A, dengan ikatan yang kuat dalam satu bidang lapisan tetapi lemah antar lapisan lain. Grafena merupakan senyawa dua dimensi yang hanya terdiri dari satu lapisan, sedangkan untuk struktur ikatan yang terdapat pada grafena sama seperti alotrop karbon yang berbentuk tiga dimensi (Royal Swedish Academy, 2010).

\section{Pelepah Sawit}

Pelepah kelapa sawit meru-pakan salah satu limbah padat pengolahan minyak sawit yang belum banyak pemanfaatannya. Kandungan senyawa 
kimia penyusun pada pelepah kelapa sawit terdiri dari selulosa, hemiselulosa, dan lignin secara berurutan yaitu 31.7\%, 33.9\% dan 17.4\% (Pope, 1999). Bahan organik yang mengandung lignin, hemiselulosa, dan selulosa dapat dimanfaatkan sebagai bahan baku karbon, karena lignin dan selulosa sebagian besar tersusun dari unsur karbon. Pelepah kelapa sawit termasuk bahan dengan kandungan selulosa yang cukup tinggi dan memiliki massa jenis lebih daripada kayu yaitu sebesar $1,16 \mathrm{~g} / \mathrm{cm}^{3}$ (Pope, 1999).

\section{METODOLOGI PENELITIAN}

Penelitian ini termasuk jenis penelitian studi literatur, dengan menggunakan sumber-sumber hasil penelitian yang telah dilakukan dan relevan terhadap tujuan yang ingin dicapai.

Peralatan yang digunakan untuk penelitian ini adalah seperangkat gelas, oven, furnace, ayakan (270 mesh), mortal dan alu, crucible keramik, spatula, neraca analitik, sentrifugasi, XRD (X-Ray Difraction), FTIR (Fourier Transform
Infra Red) dan SEM (Scanning Electron Microscope).

Sampel yang digunakan dalam penelitian ini adalah pelepah dari pohon sawit yang berumur dewasa-tua (14-20 tahun) sebanyak $1 \mathrm{~kg}$. Sampel pelepah sawit diperoleh dari perkebunan sawit di daerah Mendalo Darat, Kabupaten Muaro Jambi, Provinsi Jambi. Bahan yang digunakan dalam penelitian ini adalah $\mathrm{H}_{2} \mathrm{SO}_{4} 98 \%, \mathrm{NaNO}_{3}, \mathrm{KMnO}_{4}$, $\mathrm{H}_{2} \mathrm{O}_{2}$, akuademineral, $\mathrm{HCl} 5 \%, \mathrm{HCl}$ $35 \%$ dan logam $\mathrm{Zn}$.

\section{Karbonisasi Pelepah Sawit}

Pelepah sawit yang telah dikumpulkan, disortasi dan dipotong kecil-kecil memanjang sekitar 10-15 $\mathrm{cm}$. Lalu dikeringkan selama 2 hari dengan bantuan sinar matahari. Kemudian dimasukkan pelepah yang telah kering ke dalam crucible keramik dan dioven pada suhu $100^{\circ} \mathrm{C}$ selama 60 menit. Lalu pelepah sawit tersebut dimasukkan kedalam furnace pada suhu $300^{\circ} \mathrm{C}$ selama 90 menit. Pelepah hasil karbonisasi digerus dan diberikan dua perlakuan : pengayakan berukuran 270 mesh dan tanpa pengayakan. Digunakan ayakan dengan ukuran yang tidak terlalu kasar dan halus yaitu ukuran pertengahan (270 mesh). Tujuannya untuk mengetahui pengaruh 
perbedaan ukuran sampel terhadap hasil sintesis yang diperoleh.

\section{Sintesis Grafit Oksida}

Grafit oksida (GO) disintesis dengan metode Hummers melalui oksidasi bubuk arang pelepah sawit (Taufantri, et al. 2016). Bubuk arang kelapa sawit $(1 \mathrm{~g})$ dan $\mathrm{NaNO}_{3}(1 \mathrm{~g})$ dicampur $25 \mathrm{~mL} \mathrm{H} \mathrm{SO}_{4}$ (98\%) dalam erlenmeyer $100 \mathrm{~mL}$ dengan ice bath dibawahnya $\left(0-5^{\circ} \mathrm{C}\right)$ sambil diaduk terus menerus. Campuran diaduk selama 2 jam pada suhu ini dan $\mathrm{KMnO}_{4}$ (3 $\left.\mathrm{g}\right)$ ditambahkan pada suspensi dengan perlahan. Kecepatan penambahan dikendalikan untuk menjaga suhu reaksi agar lebih rendah dari $15^{\circ} \mathrm{C}$. Ice bath lalu dialihkan dan campuran diaduk pada $35^{\circ} \mathrm{C}$ sampai menjadi kecoklatan pucat dan terus diaduk selama 2 hari. Campuran kemudian diencerkan dengan penambahan $100 \mathrm{~mL}$ akuademineral. Suhu reaksi akan cepat meningkat menjadi $98^{\circ} \mathrm{C}$ dengan gelembung dan warna berubah menjadi warna coklat. Selanjutnya larutan ini diencerkan dengan menambahkan $200 \mathrm{~mL}$ akuademineral dan diaduk terusmenerus. Larutan akhirnya ditambahkan $10 \mathrm{~mL} \quad \mathrm{H}_{2} \mathrm{O}_{2}$ untuk mengakhiri reaksi ditandai dengan perubahan menjadi warna kuning.

Untuk pemurnian, campuran tersebut dicuci dan disentrifugasi dengan $10 \% \mathrm{HCl}$ dan aquademineral beberapa kali. Hasil sentrifugasi disaring menggunakan kertas saring whatman GF/D (berukuran 2,7 $\mu \mathrm{m}$ ) dan dikeringkan dengan vakum pada suhu kamar. Grafit oksida (GO) yang diperoleh sebagai bubuk.

\section{Reduksi Grafit Oksida menjadi}

Grafena (Taufantri, et al, 2016)

Sebanyak $40 \mathrm{mg}$ grafit oksida ditambahkan $40 \mathrm{~mL}$ akuademineral dan diaduk selama 1 jam kemudian dilakukan ultrasonikasi pada pancaran gelombang ultrasonik $50 / 60 \mathrm{~Hz}$ selama 90 menit untuk mendapatkan larutan yang homogen. Grafit oksida direduksi dengan penambahan $0,8 \mathrm{~g} \mathrm{Zn}$ dan 10 $\mathrm{mL} \mathrm{HCl} 35 \%$, kemudian diaduk selama 1 jam. Setelah 1 jam pengadukan, larutan ditambahkan lagi $10 \mathrm{~mL} \mathrm{HCl}$ $35 \%$ dan diikuti proses pengadukan selama 5-30 menit, kemudian dicuci dengan menggunakan akuademineral dan $\mathrm{HCl} 5 \%$. Proses pencucian dilakukan berulang kali menggunakan akuades sampai $\mathrm{pH}$ campuran menjadi netral. Hasil endapan pada proses 
pencucian dimasukkan ke dalam tabung stainless steel dan dipanaskan pada suhu $160^{\circ} \mathrm{C}$ selama 18 jam.

Karakterisasi Grafena (Taufantri, et al, 2016 dan Syakir, et al, 2015)

Karakterisasi grafena dari
limbah pelepah sawit diuji
menggunakan instrument XRD ( $X$ Ray Diffraction) untuk analisis struktur 2D, FTIR (Fourier Transform Infra Red) untuk mengetahui konfigurasi ikatan pada grafena hasil sintesis (gugus fungsi), dan SEM (Scanning Electron Microscope) untuk menentukan topografi (bentuk 3D) nanomaterial grafena dari limbah pelepah sawit.

eaksi nantinya.

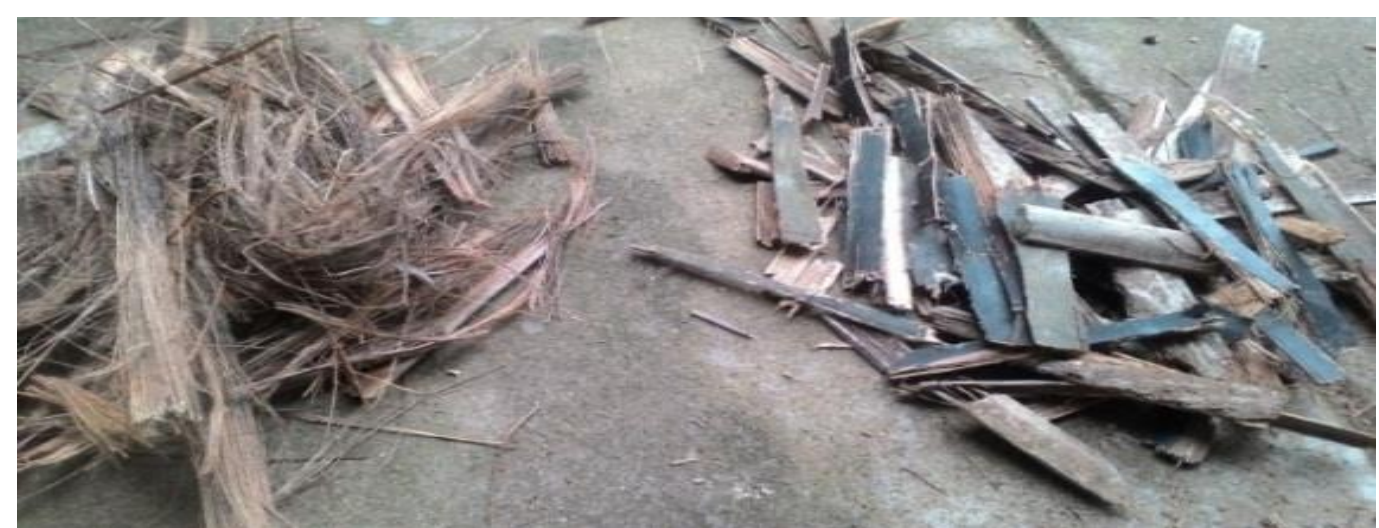

\section{Gambar 2. Hasil Sortasi Pelepah Sawit}

(Sumber : Taufantri, et al, 2016)

Selanjutnya pelepah sawit penghilangan air secara total, dan dikarbonisasi dengan cara pe- dilanjutkan dengan menggunakan ngeringan dalam oven pada suhu furnace pada suhu $300^{\circ} \mathrm{C}$ selama 60 $100^{\circ} \mathrm{C}$ selama 60 menit untuk menit hingga menjadi arang. Arang Oksida Menggunakan Pereduksi Zn - Meyly Ekawati Thebora S; Kurnia Nastira Ningsih; Muhammad Irhash Shalihin | 469 
hasil karbonisasi digerus untuk mendapatkan bubuk arang. Bubuk arang dibuat dalam dua variasi ukuran yaitu 270 mesh dan tanpa ayakan yang bertujuan untuk melihat pengaruh luas permukaan terhadap kualitas grafena yang akan dihasilkan. Berdasarkan hasil pengayakan, variasi ukuran 270 mesh memiliki tekstur yang lebih halus dibandingkan variasi tanpa pengayakan sehingga dipilih untuk digunakan ke tahap sintesis. Dipilih ayakan dengan ukuran pertengahan yang tidak terlalu kasar dan halus. Sampel dengan tekstur yang lebih halus (ukuran kecil) akan memberikan luas permukaan yang lebih besar sehingga dapat meningkatkan laju reaksi dalam proses aplikasi grafena untuk tahap selanjutnya.

\section{Sintesis Grafit Oksida dari Grafit}

Sintesis Grafit Oksida (GO) dilakukan dengan menggunakan metode Hummers melalui oksidasi bubuk arang pelepah sawit. Bubuk arang distirrer dengan $\mathrm{NaNO}_{3}, \mathrm{KMnO}_{4}$ dan $\mathrm{H}_{2} \mathrm{SO}_{4} 98 \%$ dengan pengaturan suhu $0-5^{\circ} \mathrm{C}$. Untuk mempertahankan keadaan pada suhu tersebut digunakan pendingin termostat dari campuran es batu dan garam.
Pengadukan dengan stirrer dilakukan selama 2 hari untuk mengoptimalkan reaksi oksidasi pada sampel. Pada perlakuan ini berlangsung reaksi oksidasi grafit menjadi grafit oksida (GO) dengan oksidator berupa $\mathrm{KMnO}_{4}$ dalam suasana asam yang menghasilkan campuran berwarna coklat tua (pengamatan secara kualitatif). Grafit dioksida menjadi grafit oksida yang memiliki atom Oksigen. Menurut penelitian Taufantri, et al (2016) adanya perubahan warna dari hijau tua pekat menjadi coklat tua yang terjadi akibat reaksi antara karbon, $\mathrm{H}_{2} \mathrm{SO}_{4}$, dan $\mathrm{KMnO}_{4}$ menunjukkan indikasi bahwa proses oksidasi karbon telah dimulai. Selama proses oksidasi, beberapa gugus fungsi seperti gugus fenol, gugus epoksi, gugus keton, gugus karboksil dan gugus karbonil terbentuk pada karbon (Shao, et al, 2012).

Gugus fungsi ini menyebabkan material bersifat sangat hidrofilik dan mudah terkelupas dalam air menjadi grafit oksida.

Tahapan akhir berupa pengenceran larutan grafit oksida dengan akuademineral disertai proses pengadukan terus-menerus agar proses penghomogenan terjadi secara 
optimal. Larutan ditambahkan $\mathrm{H}_{2} \mathrm{O}_{2}$ untuk mengakhiri reaksi oksidasi yang ditandai dengan perubahan menjadi warna kuning. Untuk pemurniannya, campuran dicuci dan disentrifugasi dengan $\mathrm{HCl} 5 \%$ dan aquademineral selama beberapa kali. $\mathrm{HCl}$ berfungsi untuk melarutkan logam pengotor dan aquademineral yang befungsi untuk menetralkannya. Hasil sentrifugasi disaring dan endapan dikeringkan dengan vakum pada suhu kamar. Grafit oksida (GO) hasil sintesis penelitian ini diperoleh berupa bubuk.

\section{Reduksi Grafit Oksida menjadi}

Grafena (Taufantri, et al, 2016)

Berdasarkan hasil penelitian Taufantri, et al (2016) grafit oksida yang dihasilkan selanjutnya direduksi menjadi grafena. Grafit oksida direduksi oleh reduktor $\mathrm{Zn}$ dan dilakukan dalam suasana asam (menggunakan $\mathrm{HCl}$ ). Reduktor $\mathrm{Zn}$ dalam reaksi reduksi grafit oksida berfungsi untuk mengembalikan cacat struktural pada kisi karbon dengan mengembalikan konjugasi $\pi$ dan untuk menghilangkan gugus fungsi. Gugus epoksi membentuk gugus hidroksi akibat reaksi $\mathrm{Zn}$ dengan $\mathrm{HCl}$. Gugus hidroksi juga dihasilkan pada saat reduksi gugus karbonil. Adanya gugus hidroksi pada kondisi asam menyebabkan terlepasnya hidrogen dan menghasilkan olefin (Taufantri, et al, 2016). Gambar 3 menunjukkan reaksi sintesis grafena

secara keseluruhan.

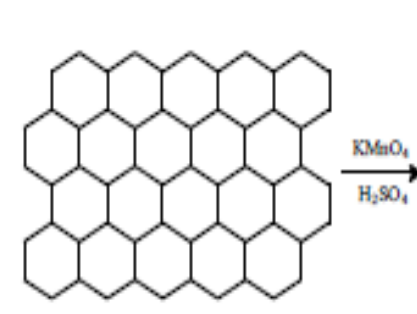

orat

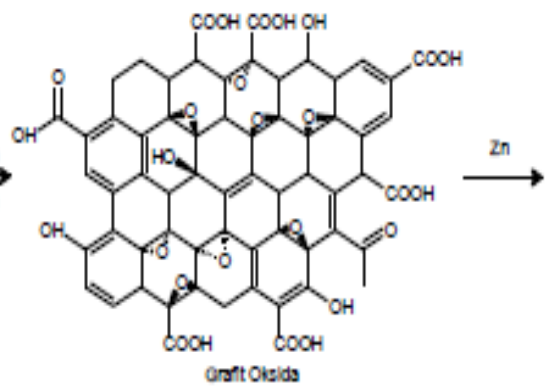

Gambar 3

Reaksi Oksidasi Grafit Menjadi Grafit Oksida Dan Reduksi Menjadi Grafena (Sumber : Taufantri, et al, 2016)

Digunakan juga sonifikasi lembaran-lembaran grafena. Kemudian untuk membantu pelepasan dicuci dengan menggunakan $\mathrm{HCl} 5 \%$ 
dan akuades sampai $\mathrm{pH}$ campuran menjadi netral. Hasil endapan dikeringkan pada suhu $160^{\circ} \mathrm{C}$ selama 18 jam.

\section{Karakterisasi Grafena}

Berdasarkan penelitian
oleh
Taufantri, et al (2016) dan

Syakir, et al (2015).

\section{XRD}

Pengamatan hasil uji sintesis grafena dilakukan menggunakan XRD dengan difraksi sinar $\mathrm{x}$ pada sudut $2 \theta=$ 50-900 dan $\lambda$ Cu-Ka $1.54060 \AA$. Gambar 4 menunjukkan difraktogram grafit, grafit oksida

da

n grafena berdasarkan penelitian Taufantri, et al (2016).
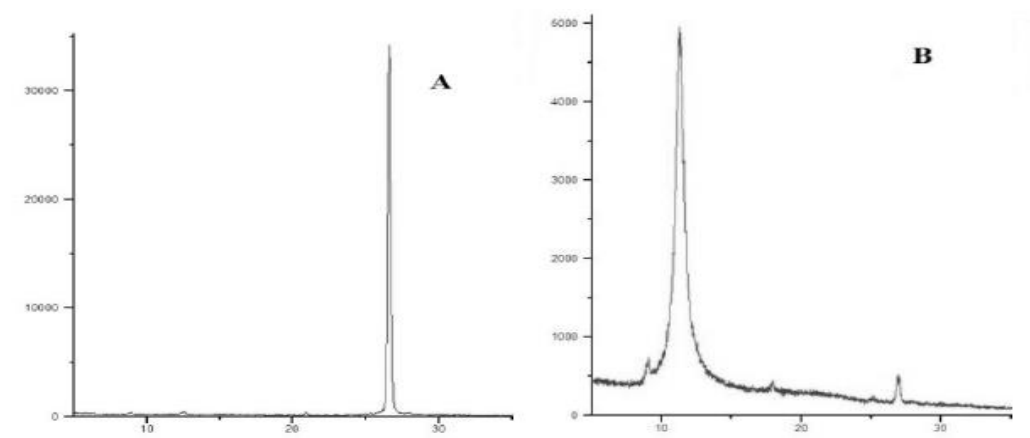

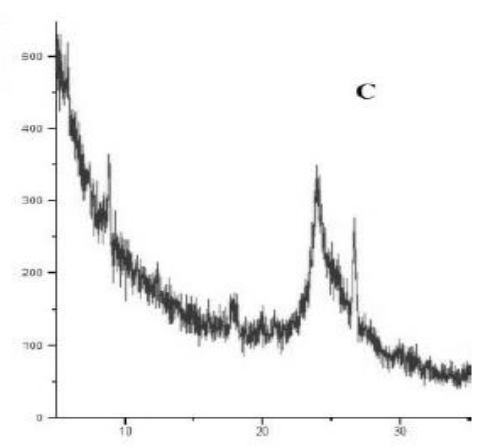

Gambar 4. Hasil XRD (a) Grafit; (b) Grafit Oksida; dan (c) Grafena (Sumber : Taufantri, et al, 2016)

Pada gambar (4a) dapat diamati puncak grafit yang muncul adalah 26.5872 dengan $d$-spacing

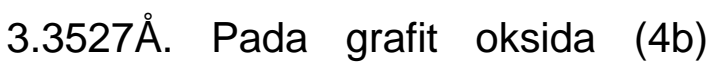
membentuk puncak baru yaitu 11.2055 dengan $d$-spacing $7.8965 \AA$. Adanya perubahan pola sudut $\mathrm{XRD}$ yang bergeser ke arah kiri lebih rendah menunjukkan terjadinya perubahan material sifat kristalinitas grafit oksida menjadi berkurang. Pelebaran jarak antar lapisan dari grafit sebesar $3.3527 \AA ̊$ menjadi grafit oksida sebesar $7.8965 \AA$ terjadi karena terbentuknya gugus fenol, gugus epoksi, gugus keton, gugus karboksil dan gugus karbonil. Penambahan molekul $\mathrm{H}_{2} \mathrm{O}$ dan gugus oksigen juga menyebabkan grafit oksida memiliki $d$-spacing yang lebih lebar.

Pola XRD grafena (Gambar 4c) hasil proses reduksi menunjukkan puncak yang muncul adalah 23.9369 
dengan $d$-spacing 3.7176 Å. Perubahan jarak $d$-spacing ini menunjukkan bahwa proses reduksi grafit oksida telah berjalan dengan baik. Pergeseran sudut $2 \theta$ ke arah kanan terjadi pada saat transformasi grafit oksida menjadi grafena yang disebabkan oleh hilangnya gugus fenol, gugus epoksi, gugus keton, gugus karboksil dan gugus karbonil pada grafit oksida karena proses reduksi (Taufantri, et al, 2016). Sedangkan grafik XRD grafena dari arang ampas tebu, muncul puncak pada sudut $2 \theta 26,427^{\circ}$ dengan nilai $d$-spacing 0,336993 $\mathrm{nm}$ (Sutayasa dan Sanjaya, 2016).

Hasil difraktogram grafena menunjukkan bahwa material cenderung berubah menjadi amorf atau tingkat kristalinitasnya berkurang. Dari pola XRD pada grafena dapat diamati bahwa terdapat puncak lain di sebelah puncak grafena yang teridentifikasi sebagai puncak grafit. Puncak grafit ini memiliki sudut 26.6644 dengan $d$ spacing $3.3432 \AA$. Pola puncak grafit muncul dise-babkan karena grafit oksida pada saat proses reduksi tidak bereaksi dan menjadi pengotor pada material grafena (Taufantri, et al, 2016).

\section{FTIR}

Gambar 5 menunjukkan spektrum serapan infra merah Grafit dan Grafit Oksida berdasarkan penelitian Syakir, et al (2015).

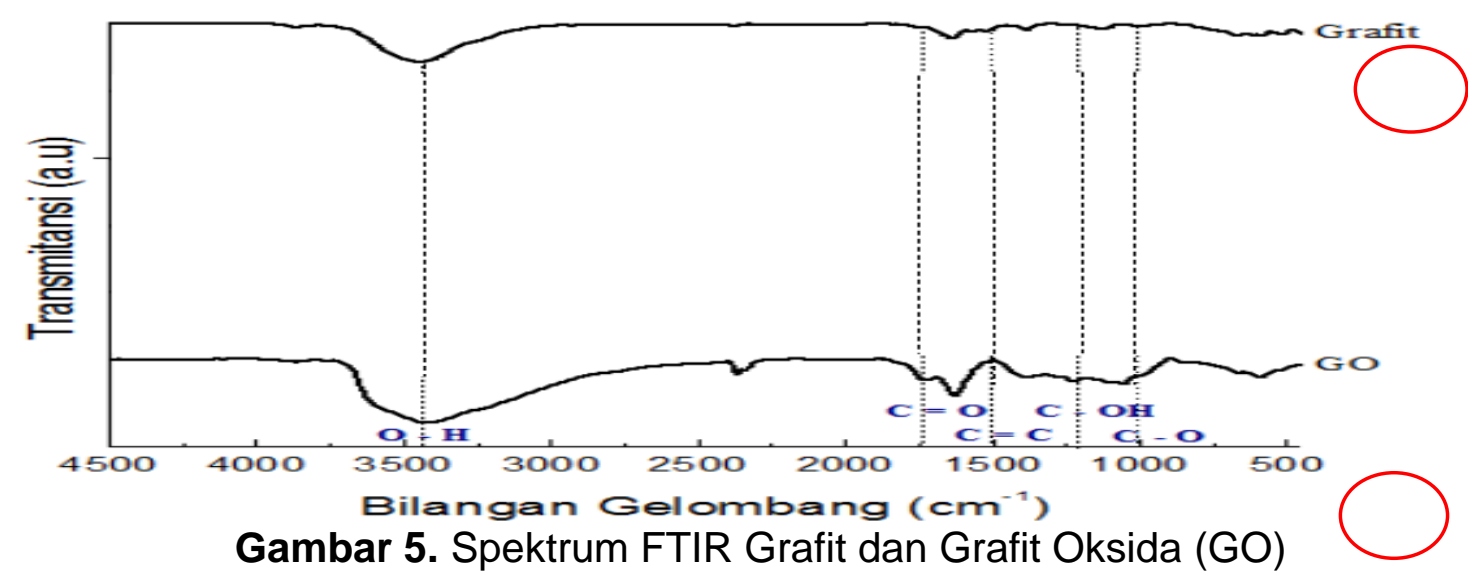

(Sumber : Syakir, et al, 2015)

Spektrum FTIR dari grafit dan menunjukkan adanya ikatan $\mathrm{O}-\mathrm{H}$. Hal grafit oksida memunculkan puncakini menandakan adanya molekul air puncak transmitansi sekitar bilangan gelombang $3400 \quad \mathrm{~cm}^{-1}$ yang dan gugus fungsi hidroksil pada sampel. Vibrasi pada sekitar bilangan 
gelombang $1700 \mathrm{~cm}^{-1}$ berkaitan dengan ikatan $\mathrm{C}=\mathrm{O}$ yang berkaitan dengan gugus karboksil yang terletak pada tepi lapisan GO.

Selain itu tampak pula adanya gugus fungsi keton dan kuinon. Selanjutnya vibrasi pada bilangan gelombang $1200 \mathrm{~cm}^{-1}$ dan $1050 \mathrm{~cm}^{-1}$ berkaitan dengan kehadiran ikatan C-OH dan C-O (Syakir, et al, 2015).

SEM

Gambar 6 menunjukkan pengamatan morfologi grafena yang diuji dengan SEM berdasarkan penelitian Taufantri, et al (2016).

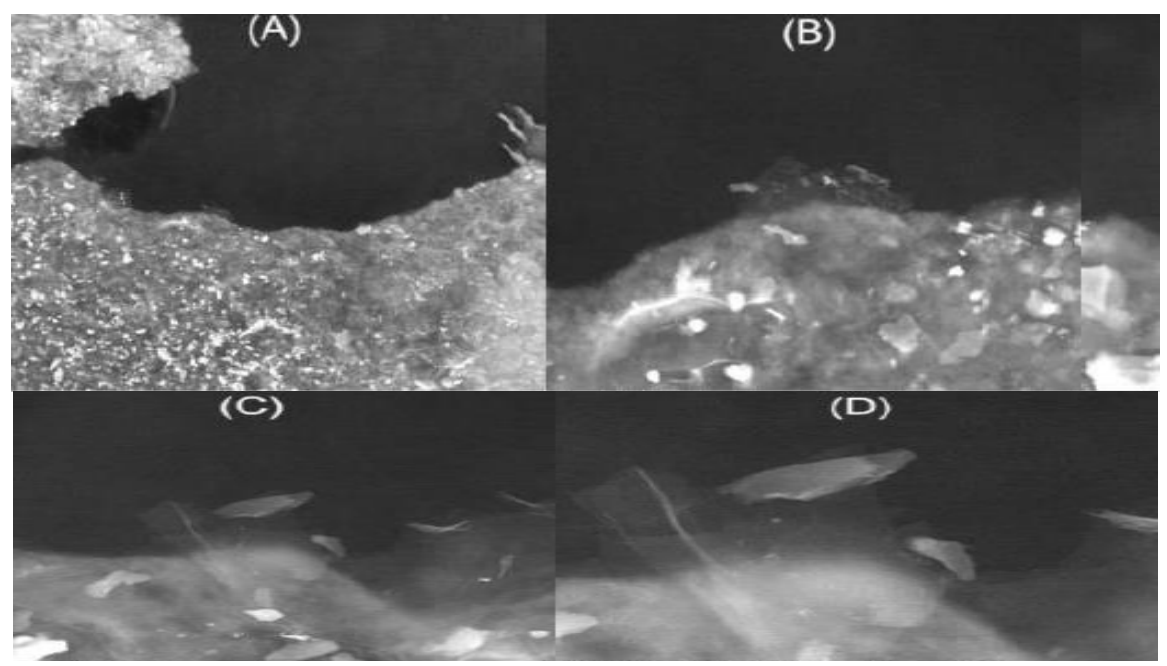

Gambar 6

Hasil SEM Grafena Perbesaran (a) 500 kali; (b) 2500 kali; (c) 5000 kali;

dan (d) 10000 kali

(Sumber : Taufantri, et al, 2016)

Hasil SEM dari penelitian dalam dan pada per-besaran 500 kali Taufantri, et al (2016) menunjukkan (gambar 6A) tampak adanya pola grafena berbentuk lembaran yang lebih bintik atau pengotor. Pola bintik yang tipis dari grafit oksida. Lembaran muncul ini menan-dakan adanya grafena terdiri dari satu lapis struktur kelemahan dari hasil penelitian ini yaitu heksagonal planar sehingga tampak proses pencucian pada tahap reduksi agak transparan yang terdiri atas grafit oksida masih kurang bersih yang single layer dan multi layer. menga-kibatkan masih tersisanya grafit Pengamatan grafena pada perbesaran 10000 kali (gambar 6D) menunjukkan yang tidak bereaksi saat direduksi (Taufantri, et al, 2016).

lembaran grafena yang menekuk ke 


\section{KESIMPULAN}

1. Sintesis grafena dari limbah pelepah sawit menggunakan metode Reduksi Grafit Oksida (GO) dengan Reduktor Zn. Grafit Oksida disintesis menggunakan metode Hummers melalui oksidasi bubuk arang pelepah sawit dengan ukuran 270 mesh. Diberikan variasi ukuran bubuk arang pelepah sawit yaitu dengan pengayakan ukuran pertengahan (270 mesh) dan tanpa pengayakan.

2. Karakterisasi Grafena menggunakan analisis XRD, FTIR dan SEM. XRD untuk menganalisis struktur 2D; FTIR untuk mengetahui konfigurasi ikatan pada grafena hasil sintesis (gugus fungsi); dan SEM untuk menen-tukan topografi (bentuk 3D) nanomaterial grafena dari limbah pelepah sawit.

\section{SARAN}

Penelitian ini perlu dikembangkan lagi dalam mencari sumbersumber karbon alami yang melimpah dan murah. Serta perlu dilakukan tahapan sintesis sampai selesai (yaitu tahapan karakterisasi) untuk mengetahui hasil sintesis yang sesungguhnya. Untuk penelitian lebih lanjut juga perlu dilakukan pengembangan dari segi metode yang lebih efektif dan sederhana sehingga dapat memudahkan proses sintesis nantinya.

\section{UCAPAN TERIMA KASIH}

Terimakasih kepada Bapak Kepala BALITBANGDA Provinsi Jambi, dosen pembimbing Dr. Drs. Ngatijo, M.Si, tim penelitian Nurmawati Lase, S.Si., Rismatua Oktafiani Sirait, S.Si. dan Puja Iklima, S.Si.

\section{DAFTAR PUSTAKA}

Darmayanti, S. 2016. "Penyerapan Logam Tembaga dalam Air Limbah dengan Menggunakan Karbon Aktif dari Pelepah Kelapa Sawit". Laporan Akhir. Politeknik Negeri Sriwijaya.

Direktorat Jenderal Ketenagalistrikan. 2017. Statistik Ketenagalistrikan 2017. Jakarta : Kementrian Energi dan Sumberdaya Mineral Republik Indonesia.

Direktorat Jenderal Perkebunan. 2017. Statistik Perkebunan Indonesia Komoditas Kelapa Sawit 20152017. Jakarta: Kementerian Pertanian.

Ginting, S.P dan J. Elizabeth. 2013. Teknologi Pakan Berbahan Dasar Hasil Sampingan Perkebunan Kelapa Sawit. Lokakarya Sistem Integrasi Kelapa Sawit-Sapi. Loka Penelitian Kambing Potong Sei Putih, Galang, Sumatera Utara: Pusat Penelitian Kelapa Sawit.

Kementrian Energi dan Sumberdaya Mineral Republik Indonesia. 2018. Handbook of Energy \& Economic Statistics of Indonesia 
(Final Edition). Jakarta: Kementrian Energi dan Sumberdaya Mineral.

Li, X., T. Zhao., Q. Chen., P. Li., K. Wang., M. Zhong., J. Wei., D. Wu., B. Wei dan H. Zhu. 2013. "Flexible All Solid-State Supercapacitors Based On Chemical Vapor Deposition Derived Graphene Fibers". Physical Chemistry Chemical Physics. Vol 15(41) : 17752.

Pope. 1999. Pembuatan Arang Aktif dari Cangkang Kelapa Sawit. Online (http://eprints,polsri. ac.id./831/3/BAB\%20II\%20Fergi n.pdf). Diakses 26 Mei 2018.

Royal Swedish Academy, O. F. Sciences. 2010. "Graphene: Scientific Background on the Nobel Prize in Physics 2010." The Royal Swedish Academy of Sciences 50005: 0-10.

Samantara, A.K. 2015. Graphene : Synthesis, Properties and Application. India : KIIT University.

Shao, G., Y. Lu., F. Wu., C. Yang., F. Zeng dan Q. Wu. 2012. "Graphene Oxide: The Mechanisms of Oxidation and Exfoliation". J. Mater. Sci. Vol 47 (10): 4400-4409.

Stoller, M.D., S. Park., Y. Zhu., J. An dan R.S. Ruoff. 2008. "Graphene-Based Ultracapacitors". Nano Letters. Vol 8 (10): 3498-3502.

Sutayasa, L.P dan I.G.M. Sanjaya. 2016. "Karakterisasi Graphene Arang Ampas Tebu Berbasis X$\mathrm{RD}$ dan TEM". UNESA Journal of Chemistry: 23-27.
Syakir, N., R. Nurlina., S. Anam., A. Aprilia., S. Hidayat dan Fitrilawati. 2015. "Kajian Pembuatan Oksida Grafit untuk Produksi Oksida Grafena dalam Jumlah Besar". Jurnal Fisika Indonesia. Vol XIX (55): 26-29.

Taufantri, Y., Irdhawati., I.A. Raka dan A. Asih. 2016. "Sintesis dan Karakterisasi Grafena dengan Metode Reduksi Grafit Oksida Menggunakan Pereduksi Zn". Jurnal Kimia VALENSI: Jurnal Penelitian dan Pengembangan IImu Kimia. Vol 2(1): 17-23.

Yusupandi, F. 2017. Graphene Ball : Material Baru yang Mampu Melakukan Full Charging dalam Waktu 12 Menit. Online (https://warstek.com/2017/12/14 / graphene-ball/). Diakses 23 Oktober 2019 